\title{
Circulating tumour markers can define patients with normal colons, benign polyps, and cancers
}

\author{
R Mead', M Duku', P Bhandari' and IA Cree \\ 'Department of Gastroenterology and Translational Oncology Research Centre, Queen Alexandra Hospital, Portsmouth PO6 3LY, UK
}

\begin{abstract}
BACKGROUND: Early diagnosis represents the best opportunity for cure of colorectal cancer. Current screening programmes use faecal occult blood testing for screening, which has limited sensitivity and poor specificity.

METHODS: In this study we looked at a series of previously described diagnostic markers utilising circulating free DNA (cfDNA), with a preparation method allowing small DNA fragments to be isolated. The Circulating free DNA was isolated from samples obtained from 85 patients, including 35 patients without endoscopic abnormality, a group of 26 patients with benign colorectal adenomas, and 24 patients with colorectal carcinomas. In each case, polymerase chain reaction (PCR) was performed for Line I 79 bp, Linel 300 bp, Alu II 5 bp, Alu 247 bp, and mitochondrial primers. In addition, carcinoembryonic antigen (CEA) was measured by ELISA. Each marker was analysed between normal, polyp, and cancer populations, and the best performing analysed in combination by logistic regression.

RESULTS: The best model was able to discriminate normal from populations with adenoma or carcinoma using three DNA markers and CEA, showing an area under the receiver operator characteristic (ROC) curve of 0.855 with a positive predictive value of $81.1 \%$ for polyps and cancer diagnosis.

CONCLUSION: These circulating markers in combination with other markers offer the prospect of a simple blood test as a possible secondary screen for colorectal cancers and polyps in patients with positive faecal occult blood tests.

British Journal of Cancer (201 I) I 05, 239-245. doi:I0.1038/bjc.20 I I.230 www.bjcancer.com

Published online 28 June 2011

(c) 20II Cancer Research UK
\end{abstract}

Keywords: colorectal cancer; circulating; DNA; plasma; CEA; tumour marker

Colorectal cancer is the second most common cause of death from cancer in the United Kingdom, and the third most common cancer overall. Approximately 100 new cases of colorectal cancer are diagnosed each day, and 16000 people die from this disease each year in the United Kingdom (Cancer Research UK, 2011). The disease biology is well understood with a sequence of adenoma, increasing dysplasia, and carcinoma commonly demonstrated (Allen, 1995; Vogelstein and Kinzler, 2004). Death is secondary to widespread metastasis, particularly involving the liver, which does not occur in dysplasia and early cancer restricted to the bowel wall. Therefore, early diagnosis represents the best opportunity for cure.

The United Kingdom is fortunate in having an established bowel cancer screening programme. However, this relies upon patients sampling their own faeces up to nine times with a guaiac-based occult blood test (fOBT). Although practical and affordable, this system leaves room for improvement (Vernon, 1997; van Dam et al, 2010), with initial UK compliance rates at 56.8\% (http:// www.cancerscreening.nhs.uk/bowel/), and considerable variation worldwide (18-90\%) (Ore et al, 2001; Federici et al, 2005; Fenocchi et al, 2006; Parente et al, 2009). The fOBT also has a low estimated sensitivity for cancer $(40.58 \%)$, and even lower sensitivity for significant dysplastic polyps (5.00\%) (http://www.cancerscreening. nhs.uk/bowel/). Current treatment options offer cure in $90-100 \%$

*Correspondence: Professor IA Cree; E-mail: ian.cree@porthosp.nhs.uk Revised 27 April 201 I; accepted 26 May 201 I; published online 28 June 2011 of patients with dysplasia and early cancers (Cancer Research UK, 2011); however, identification of these often asymptomatic patients remains challenging.

In cancer patients, the presence of circulating free DNA (cfDNA) in the blood has been well described (Boni et al, 2007; Tomita et al, 2007; Catarino et al, 2008; Kolesnikova et al, 2008; Sunami et al, 2008; Toth et al, 2009; Yoon et al, 2009; Ellinger et al, 2009a, b; Dobrzycka et al, 2010; Liggett et al, 2010; van der Drift et al, 2010), and is considered to be a derivative of increased and abnormal apoptotic pathways in the cancerous lesions (Stroun et al, 2001; Tuaeva et al, 2008). The abnormal DNA degradation or secretion (Stroun et al, 2001) leads to increased DNA levels and differing DNA fragmentation, readily identifiable with standardised and affordable molecular biology techniques (Drew, 2007).

Studies of cfDNA in both plasma and serum have been reported with promising markers identified (Boni et al, 2007; Tomita et al, 2007; Catarino et al, 2008; Kolesnikova et al, 2008; Sunami et al, 2008; Toth et al, 2009; Yoon et al, 2009; Ellinger et al, 2009a, b; Dobrzycka et al, 2010; Liggett et al, 2010; van der Drift et al, 2010). However, differing levels of cfDNA are found between and within experiments using serum and plasma, and the optimal method for processing blood is still debated (Kopreski et al, 1997; Chiu et al, 2001; Taback et al, 2004; Umetani et al, 2006b; Board et al, 2008; Xue et al, 2009; Yoon et al, 2009; Thierry et al, 2010; van der Vaart and Pretorius, 2010). DNA purification techniques have recently improved, allowing purification of small $(20+\mathrm{bp})$ cfDNA fragments. Small fragment DNA has been suggested as an 
important component of circulating DNA in cancer patients (Rago et al, 2007; Muller et al, 2008; Thierry et al, 2010), and has not previously been included in many studies isolating $>100 \mathrm{bp}$ fragments (Wang et al, 2004; van der Vaart and Pretorius, 2010).

Raised levels of cfDNA have been identified in patients with inflammatory conditions and in patients admitted to hospital for medical treatment suggesting increased apoptosis in these nonneoplastic conditions (Harbeck et al, 1975; Holdenrieder et al, 2001; Chang et al, 2002; Lam et al, 2004; Margraf et al, 2008; Perego et al, 2008). Raised cfDNA levels cannot therefore be regarded as specific to cancer, although different size distributions have been noted in cancer patients (Wang et al, 2003; Ellinger et al, 2008). As cfDNA lacks specificity, it is potentially useful to combine its assessment with other markers. Carcinoembryonic antigen (CEA) is used clinically as a marker of colorectal cancer progression, but alone is not useful as a diagnostic marker (Locker et al, 2006). Nevertheless, we felt it useful to include CEA in our analysis as it is readily available and could be assessed for its contribution to the multimarker model.

The aim of this study was to confirm the presence of previously described diagnostic markers in sera (Umetani et al, 2006a, c; Diehl et al, 2008; Sunami et al, 2008), test the addition of mitochondrial and small fragment DNA markers (Diehl et al, 2005; Lin et al, 2008), and optimise them for analysis in plasma (Chiu et al, 2001; Kirsch et al, 2008), a source less likely to be contaminated from leukocytes (Lee et al, 2001; Jung et al, 2003; Taback et al, 2004; Yoon et al, 2009; Thierry et al, 2010; van der Vaart and Pretorius, 2010). With a cleaner source, and purification including small fragment DNA, we aimed to identify changes in plasma from patients without known inflammatory conditions undergoing either colonoscopy to remove large precancerous lesions or curative surgery for colon cancer.

\section{PATIENTS AND METHODS}

\section{Patient selection}

Participants were screened for inflammatory conditions and previous cancer by history, patient letters, and recent blood tests before consent. Patients undergoing endoscopic investigation without significant clinical findings were included as a 'normal' control group. Blood samples were taken after the normal investigation. Patients undergoing therapeutic endoscopy for large benign polyps had samples taken before endoscopic intervention commenced. This group included patients with low-grade dysplasia, high-grade dysplasia, and polyp cancers, and grouped according to the highest-grade polyp. Patients with established colorectal cancer were admitted to surgical wards before attempted surgical cure, and samples were taken as part of the preoperative work-up.

\section{Sample processing}

Venous blood was transferred in BD Vacutainer EDTA tubes (Becton Dickinson, Oxford, UK) and processed within 1-4h (Lee et al, 2001; Xue et al, 2009). Samples were mixed with same volume of phosphate-buffered solution before layering over Histopaque1077 (Sigma-Aldrich Ltd, Poole, UK) and centrifuging for $30 \mathrm{~min}$ at $600 \mathrm{~g}$. The clear plasma above the separated cellular layer was carefully removed without disturbance to the cellular layer. Further centrifugation at $400 \mathrm{~g}$ for $7 \mathrm{~min}$ was carried out before removing the upper layer of plasma with a sterile pastette (without disturbing the lower levels). Samples were divided into $2 \mathrm{ml}$ aliquots and stored at $-80^{\circ} \mathrm{C}$.

Before DNA purification, plasma samples were thawed and spun at $11000 \mathrm{~g}$ for $3 \mathrm{~min}$. DNA was purified with a modified high-yield Nucleospin Plasma XS protocol, using $960 \mu \mathrm{l}$ of plasma according to the manufacturer's instructions (Macherey-Nagel, DÜren, Germany). DNA was stored at $-20^{\circ} \mathrm{C}$ in $30 \mu$ of elution buffer, and thawed only once.

\section{Polymerase chain reaction}

Polymerase chain reaction (PCR) was performed on an AB7500 PCR machine (Applied Biosystems Inc., Foster City, CA, USA). SYBR green master-mix and primers (Applied Biosystems) were optimised for Line1 $79 \mathrm{bp}$ (Diehl et al, 2008), Line1 $300 \mathrm{bp}$ (Sunami et al, 2008), Alu 115 (Umetani et al, 2006c), Alu 247 (Umetani et al, 2006c), and mitochondrial primers (Lin et al, 2008). DNA was diluted 1:40 before triplicate evaluation across five separate primer plates. A single standardised solution of lymphocyte DNA was used as a standard curve reference (identical across all five plates) (Diehl et al, 2008; Sunami et al, 2009). Mean values across triplicates were used for further analysis.

\section{Total DNA analysis}

DNA quantification utilised PCR of the repetitive Line1 $79 \mathrm{bp}$ fragment, as described by Diehl et al (2008). Essentially, the PCR reaction was performed in triplicate against a common genomic DNA standard curve, and $5 \mu \mathrm{l}$ of $1: 40$ DNA suspension was added to $20 \mu \mathrm{l}$ of SYBR green with $400 \mu \mathrm{mol}$ Line $179 \mathrm{bp}$ primers. Total DNA in $\mathrm{ng} \mathrm{ml}^{-1}$ was calculated using the internal AB7500 standard software algorithm. Cycling conditions were $2 \mathrm{~min}$ at $50{ }^{\circ} \mathrm{C}, 10 \mathrm{~min}$ at $95^{\circ} \mathrm{C}$, and 30 cycles of $95^{\circ} \mathrm{C}$ for $15 \mathrm{~s}$, and $60^{\circ} \mathrm{C}$ for $1 \mathrm{~min}$. The assay has an intraassay coefficient of variation $(\mathrm{CoV})$ of $8.6 \%$ and the interassay $\mathrm{CoV}$ was $5.6 \%$.

\section{CEA analysis}

The CEA analysis was performed using a Beckman Coulter Unicel DXL 800 machine (CEA2 assay) with a CEA2 kit (CEA Access, Beckman Coulter ref 33200, High Wycombe, UK). This is an immunoassay with Lumi-Phos 530 (Lumigen PPD (4-methoxy-4(3-phosphatephenyl)spiro[1,2-dioxetane-3,2'-adamantane], disodium salt) as the fluorescent marker, and alkaline phosphatase as the linked enzyme. The reaction produces fluorescence at $530 \mathrm{~nm}$, which is quantitatively assayed.

Serum is the usual source of CEA, and with half-strength plasma there is no recognised clinical cutoff. The results have therefore been used quantitatively as part of a regression model, recognising this limitation.

\section{Ethical approval and data analysis}

Local ethical approval was undertaken, and samples stored according to a local tissue bank protocol. Paired data were analysed using Mann - Whitney $U$-test, and multiple group analysis by Kruskal-Wallis test. Receiver operator characteristic (ROC) analysis was used to assess for diagnostic suitability, and logistic regression analysis to analyse marker combination. Both were undertaken using SPSS ver. 16.0 (IBM United Kingdom Limited, Portsmouth, UK) with statistical advice. As an increased type I error is associated with multiple marker analysis, a 10-fold Bonferroni correction has been applied, reducing the significant $P$-value to 0.005 .

\section{RESULTS}

\section{Study population}

The study population comprised 85 patients, including 35 patients without endoscopic abnormality, a group of 26 patients with benign colorectal adenomas, and 24 patients with colorectal carcinomas. The reference 'normal' group of 35 patients, including 
15 men, was chosen as representing a typical population attending for endoscopic investigation but with no detectable abnormality (Table 1). The mean age of this group was 54.1 years (range 24-80 years). Significant intercurrent diagnoses in this group included: osteoarthritis, ischaemic heart disease, pernicious anaemia, and peptic ulcer.

The benign colorectal polyp group of 26 patients, including 14 men, had a mean age of 70.2 years (range $56-85$ years). From these patients, 29 polyps were removed, with mean size $54.3 \mathrm{~mm}$ (range 5-200 mm). Of these polyps, 18 showed low-grade dysplasia (LGD), and had a mean size of $56.1 \mathrm{~mm}$ (range 5-200 mm), whereas 11 polyps showed high-grade dysplasia (HGD), with mean size $52.5 \mathrm{~mm}$ (range $28-100 \mathrm{~mm}$ ). Significant residual polyp remained in three patients, and a further blood sample taken from these patients is included in the analysis.

The group of cancer patients included 19 men and had a mean age of 71.5 years (range 49-87 years). There were four patients with polyp cancers, with mean size $41.7 \mathrm{~mm}$ (range $25-40 \mathrm{~mm}$ ), but the majority had biopsy-proven colorectal carcinomas, with pathological staging as: pT0 $\times 5$ (4 polyps, 1 post radiotherapy); pT2 $\times 4$; pT3 $\times 14 ;$ pT4 $\times 1$.

In total, both polyp and cancer populations included 50 patients, and 53 plasma samples, with a mean age of 71.1 years (49-87 years).

\section{Individual marker utility}

Each marker was analysed between normal, polyp, and cancer populations (Table 1). There was an increase in the mean values of all markers with increasing pathological grade, although not all these differences were statistically significant (Table 2). There was no significant correlation with age in the normal population.

When compared with normal controls, patients with benign polyps had significantly raised levels of total DNA $(P<0.001)$, mitochondrial DNA $(P=0.001)$, and Alu $247 \mathrm{bp}$ fragment $(P=0.001$, Table 2 and Figure 1$)$. These markers also show the best ROC curves for diagnostic testing. The total DNA (Line1 $79 \mathrm{bp}$ ) was the best single marker $(\mathrm{ROC}=0.756$, Table 3$)$.

Table I Normal population $(n=35)$ indications for endoscopy

\begin{tabular}{lc}
\hline Endoscopy indication & Number \\
\hline Dysphagia & 5 \\
Dyspepsia & 10 \\
Ulcer follow-up & 1 \\
Haematemesis & 2 \\
Abdominal pain & 8 \\
Change in bowel habit & 7 \\
Family history of cancer & 1 \\
Anaemia & 5 \\
Polyp follow-up & 1 \\
Melaena & 1 \\
\hline
\end{tabular}

Some patients had multiple indications.
When compared with normal controls, patients with colon cancer had significantly raised levels of the fragmentation ratios Line1 79/300 $(P=0.001)$ and Alu 115/247 $(P<0.001)$ (Table 2 and Figure 2). The total DNA and the Alu $247 \mathrm{bp}$ markers also remained significantly different, with all four markers showing high ROC values. The Alu 115/247 ratio was found to be the best single ratio $(\mathrm{ROC}=0.772$, Table 3$)$ for distinguishing cancer from normal in this series.

Comparison of normal with all neoplasia patients showed total DNA $(P<0.001)$, mitochondrial DNA per ml $(P<0.001)$, and Alu $247 \mathrm{bp}(P<0.001)$ markers to be highly statistically significant. The best single marker for diagnosis of neoplasia in this population was total DNA $(\mathrm{ROC}=0.756$, Table 3$)$. There were occasional outlier results: a single patient with a LGD polyp represented an extreme outlier, with a total DNA level of $206 \mathrm{ng} \mathrm{ml}^{-1}$. This patient was removed from the mean data, but is included in all other analyses.

Carcinoembryonic antigen is currently the only circulating marker in use for colon cancer follow-up, although it has again been shown in this series that it is a poor diagnostic marker for colonic neoplasia, with no significant difference between the populations, and low ROC values (best ROC $=0.596$ ). However, its clinical role is in those with high levels already diagnosed with colonic cancer and therefore it was included as part of a panel of diagnostic markers as described below.

\section{Logistic regression analysis}

The best performing markers were combined and analysed in combination by logistic regression. The predicted probabilities of diagnosis generated a 'combination marker' ROC curve for all three categories (Table 4).

The best ROC curve to discriminate normal from neoplasia populations, with four DNA markers (Line1 $79 \mathrm{bp}$, Alu $247 \mathrm{bp}$, mitochondrial DNA, and Alu $115 \mathrm{bp}$ ), showed ROC curve of 0.810 (Figure 3A). Combining CEA levels and the combination DNA marker demonstrated the possibilities of a multiple-target blood test and showed ROC curve of 0.855 (Table 4 and Figure 3B). The final test had a positive predictive value (PPV) of $81.1 \%$ for polyps and a negative predictive value (NPV) of $73.5 \%$ (sensitivity $83 \%$ and specificity $72 \%$ ) for early cancer diagnosis. If the threshold was altered to achieve the best NPV (97.1\%), the PPV was $49.1 \%$.

\section{DISCUSSION}

Colorectal cancer carries a high mortality in the United Kingdom, and efforts to diagnose the disease at an earlier stage are regarded as key to reduce associated deaths (Richards, 2009). Screening in colorectal cancer is especially challenging with the diagnosis of precancerous adenomatous polyps regarded as essential for prevention, and representing a more difficult diagnostic target.

This study demonstrates highly significant differences between a 'normal' population, a population with adenomatous polyps, and a population with colonic cancer. Quantities and patterns of circulating DNA differ significantly between the groups, with total

Table 2 Mean values for circulating markers by pathology

\begin{tabular}{|c|c|c|c|c|c|c|c|c|}
\hline & $\begin{array}{l}\text { Age, } \\
\text { years }\end{array}$ & $\begin{array}{c}\text { CEA } \\
\mathrm{ng} \mathrm{ml}^{-1}\end{array}$ & $\begin{array}{c}\text { Total nuclear } \\
\text { DNA ng ml-1 } \\
\text { plasma }\end{array}$ & $\begin{array}{l}\text { Mitochondrial } \\
\text { DNA ng ml-1 } \\
\text { plasma }\end{array}$ & $\begin{array}{l}\text { Linel } 79 / \\
\text { Linel } 300\end{array}$ & Alu II5/247 & $\begin{array}{l}\text { Linel } 300 \\
\mathrm{ng} \mathrm{ml}^{-1} \\
\text { plasma }\end{array}$ & $\begin{array}{c}\text { Alu } 247 \mathrm{ng} \mathrm{ml}^{-1} \\
\text { plasma }\end{array}$ \\
\hline Normal & 54.1 & 0.49 & 7.96 & 0.90 & 6.67 & $|0.0|$ & 1.54 & 2.86 \\
\hline Polyps & 70.2 & 0.65 & 15.04 & 2.68 & 7.76 & 11.89 & 3.25 & 5.56 \\
\hline Cancer & 71.5 & 1.06 & 30.09 & 4.05 & 9.11 & 14.02 & 3.56 & 7.51 \\
\hline
\end{tabular}

Abbreviation: CEA = carcinoembryonic antigen. 
$\mathbf{A}$
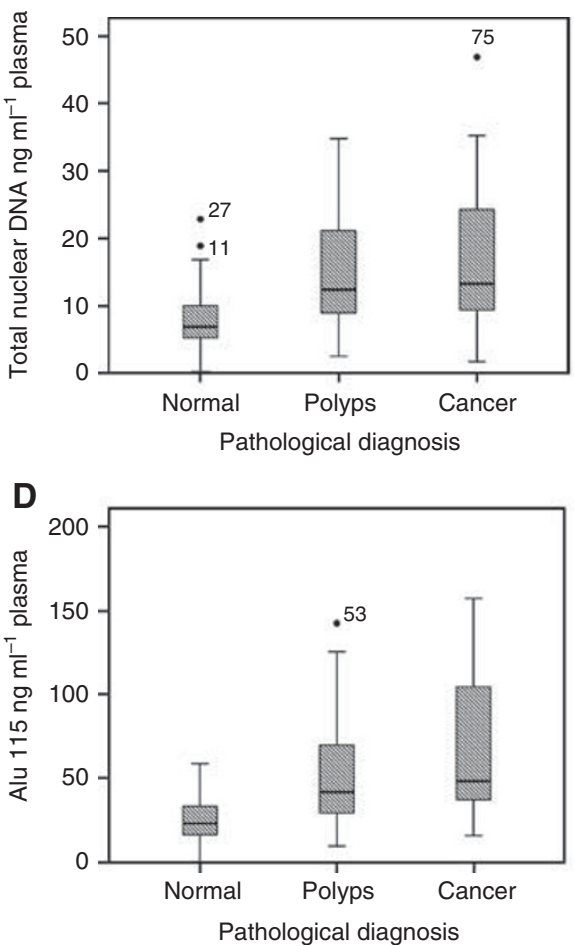

B
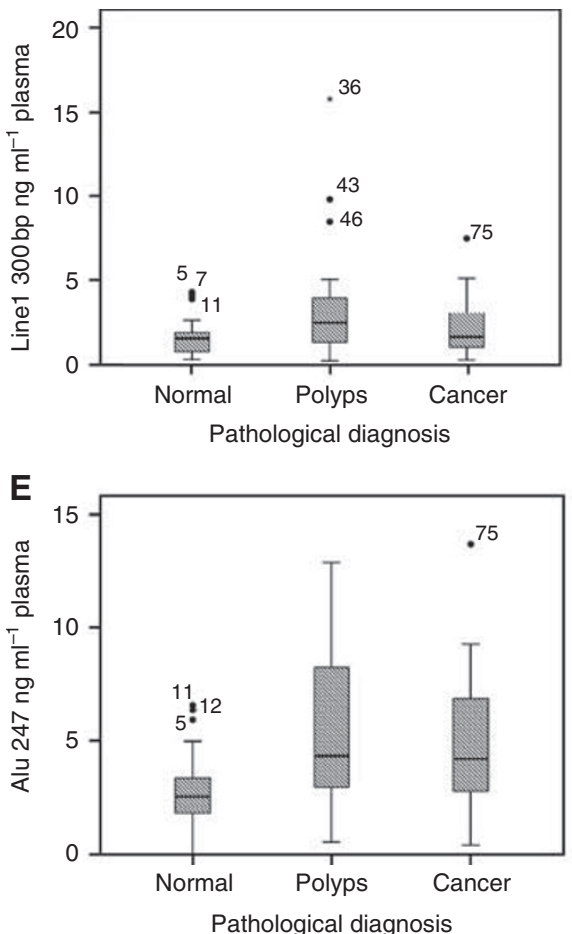

C

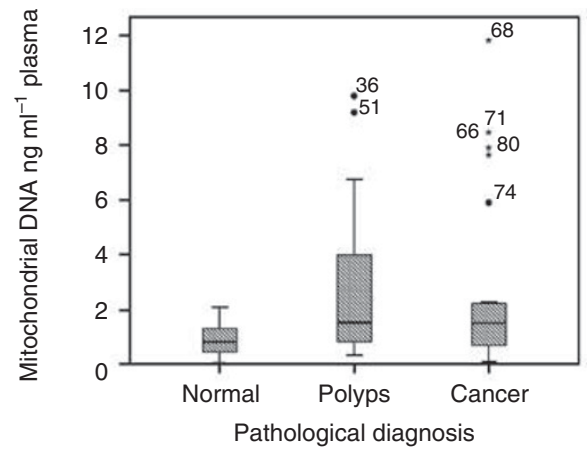

$\mathbf{F}$

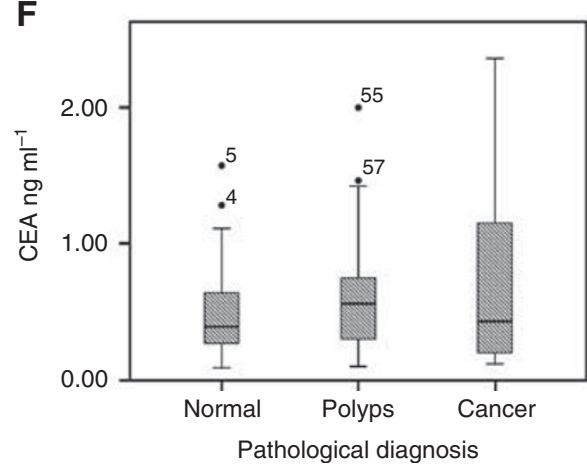

Figure I Box plots for each of the DNA markers measured showing medians as bars and interquartile range as box. (A) Total DNA expressed as the concentration of the repetitive Line 79 bp DNA fragment $(P<)$, (B) Line I 300 bp fragment, $(\mathbf{C})$ mitochondrial DNA $(P<)$, (D) Alu I I 5 fragment, (E) Alu 247 bp fragment, and (F) CEA.

Table 3 Significance testing of markers in populations with normal endoscopy, polyps, or cancer

\begin{tabular}{|c|c|c|c|c|c|c|c|}
\hline & $\begin{array}{c}\text { CEA } \\
\mathrm{ng} \mathrm{ml}^{-1}\end{array}$ & $\begin{array}{c}\text { Total nuclear } \\
\text { DNA ng ml-1 } \\
\text { plasma }\end{array}$ & $\begin{array}{c}\text { Mitochondrial } \\
\text { DNA ng ml - ' plasma }\end{array}$ & $\begin{array}{l}\text { Line I 79/ } \\
\text { Line I } 300\end{array}$ & $\begin{array}{c}\text { Alu } \\
\text { I I 5/247 }\end{array}$ & $\begin{array}{c}\text { Line I } 300 \mathrm{ng} \mathrm{ml}^{-1} \\
\text { plasma }\end{array}$ & $\begin{array}{l}\text { Alu } 247 \mathrm{ng} \mathrm{ml}^{-1} \\
\text { plasma }\end{array}$ \\
\hline Polyps vs normal & 0.254 & $P<0.001$ & 0.001 & 0.721 & 0.879 & 0.007 & 0.001 \\
\hline Cancer vs normal & 0.396 & 0.001 & 0.017 & 0.001 & $P<0.001$ & 0.174 & 0.004 \\
\hline Polyps and cancer vs normal & 0.234 & $P<0.001$ & $P<0.001$ & 0.033 & 0.043 & 0.014 & $P<0.001$ \\
\hline
\end{tabular}

Abbreviation: CEA = carcinoembryonic antigen. Mann-Whitney U-test, Bonferroni correction applied, significance level $P=0.005$.

A

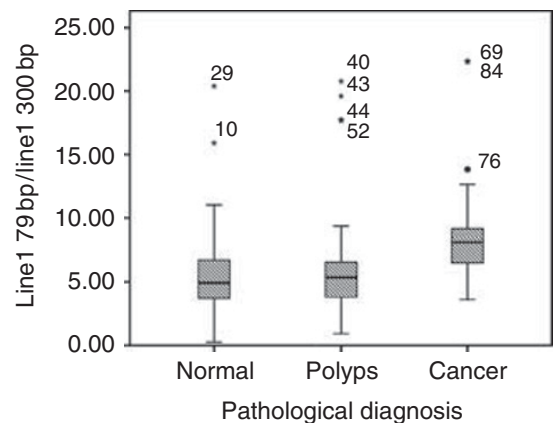

B

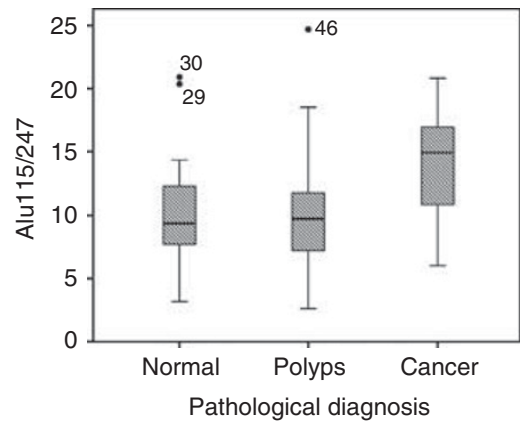

Figure 2 Box plots for ratios of the DNA markers measured showing medians as bars and interquartile range as box. (A) Linel 79/300 ratio and (B) Alu I I5/247 bp ratio.

quantities of nuclear and mitochondrial DNA increasing with pathological grade, and fragmentation patterns changing between normal, adenomatous, and cancer populations. Individual markers demonstrate good diagnostic tests, and in combination provide an improved test for both polyps and cancer $(\mathrm{ROC}=0.810)$. To our knowledge, this is the first study to demonstrate these circulating 
Table 4 ROC curve values for each marker and combination marker by pathology

\begin{tabular}{|c|c|c|c|c|c|c|c|c|}
\hline & $\underset{\text { ng ml }^{-1}}{\text { CEA }}$ & $\begin{array}{l}\text { Total nuclear } \\
\text { DNA ng ml-1 } \\
\text { plasma }\end{array}$ & $\begin{array}{l}\text { Mitochondrial } \\
\text { DNA ng ml-1 } \\
\text { plasma }\end{array}$ & $\begin{array}{l}\text { Linel } 79 / \\
\text { Line I } 300\end{array}$ & $\begin{array}{c}\text { Alu } \\
\text { I I 5/247 }\end{array}$ & 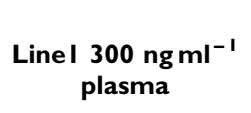 & $\begin{array}{l}\text { Alu } 247 \mathrm{ng} \mathrm{ml}^{-1} \\
\text { plasma }\end{array}$ & $\begin{array}{c}\text { Combined } \\
\text { marker }\end{array}$ \\
\hline Cancer vs normal & 0.574 & 0.757 & 0.675 & 0.759 & 0.772 & 0.594 & 0.716 & 0.863 \\
\hline Polyps and cancer vs normal & 0.586 & 0.756 & 0.713 & 0.624 & 0.629 & 0.647 & 0.724 & 0.810 \\
\hline
\end{tabular}

Abbreviations: $\mathrm{CEA}=$ carcinoembryonic antigen; $\mathrm{ROC}=$ receiver operator characteristic

A

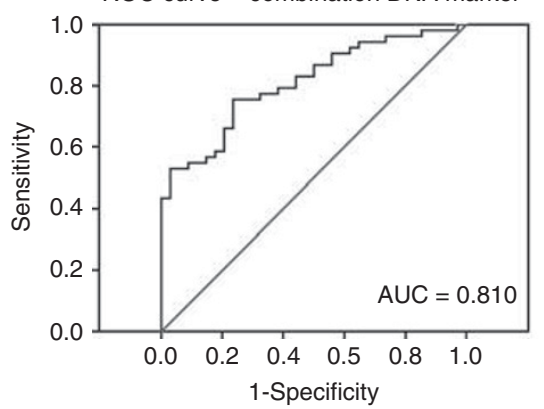

B

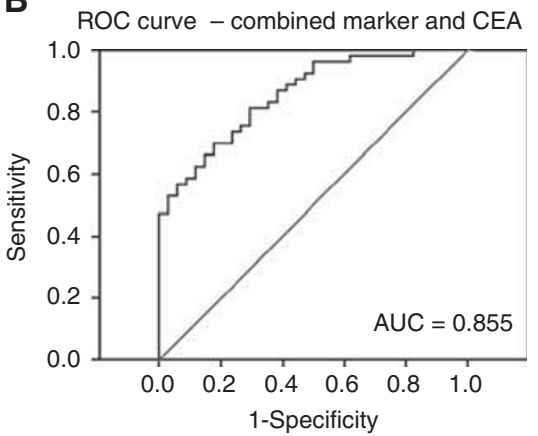

Figure 3 (A) ROC curve for the optimal combination marker-derived logistic regression from three markers (total nuclear DNA, Alu 247, and mitochondrial DNA), and (B) with CEA forced into the model.

DNA changes in colonic polyps and cancers, offering the prospect of improved diagnosis of neoplasia in colorectal cancer screening with a simple blood test. Although the test lacks specificity for colorectal cancer, it could be particularly useful as a triage test for patients with a positive faecal occult blood test. Those with cfDNA below a threshold defined by the ROC curve could be spared the risk and cost of colonoscopy.

Although a larger population would be desirable, these results arise in a clinically very relevant population with other results providing good support for our findings. Strikingly similar DNA levels in serum, from a study of more advanced colon cancers, showed a healthy control group with an almost identical median total DNA level of $7.7 \mathrm{ng} \mathrm{ml}^{-1}$ (in current study, $6.86 \mathrm{ng} \mathrm{ml}^{-1}$ ), and cancer patients with $35.8 \mathrm{ng} \mathrm{ml}^{-1}$ (in current study, $14.58 \mathrm{ng} \mathrm{ml}^{-1}$ ). A combined ROC score in cancer cases was 0.92 (Flamini et al, 2006).

Although total DNA levels are significantly different across pathological grade, neither polyp size nor estimated surface area showed significant correlation in both the total polyp population $(P=0.28)$ and the larger category of LGD polyps $(P=0.24)$. Accurate sizing of polyps is however difficult, with lateral and outward growth contributing to an overall volume; therefore, although we have found no correlation, it is difficult to be entirely confident that size of polyp is not relevant to cfDNA levels.

Mitochondrial DNA, with multiple copies in each cell, has been proposed to provide a more accurate marker in the analysis of low quantities of circulating DNA. In agreement with this, our study shows highly significant differences between the groups, with a rise in benign and cancer groups. However, in logistic regression analysis it does not add to the accuracy obtained with standard markers, and other studies have also reported both high and low levels in cancer (Huang et al, 2009; Xia et al, 2009; Hosgood et al, 2010).

Total DNA and Alu 247 fragment results have now been demonstrated to be consistent across studies in both noninflammatory normal patients and three types of cancer. We believe that they offer the prospect of a broad neoplasia screening test in noninflammatory cancers. This approach would be highly attractive to patients, although taxing for physicians in an asymptomatic population, and will require specificity for cancer type. This may be available from other tests, possibly on the same blood sample. For example, in our study the $300 \mathrm{bp}$ marker does not perform well, but has shown promise in breast cancer (Sunami et al, 2008). This difference may help localise gastrointestinal cancers from other cancer types when Alu 247 is raised. This interesting finding may relate to the biological handling of cfDNA from the digestive system before it enters the normal circulation (Gauthier et al, 1996; Taback et al, 2006), and may give the Alu $247 \mathrm{bp}$ fragment a degree of specificity for colorectal neoplasia. Alternatively, specificity may be achieved by using additional PCR markers such as methylated septin 9 or ELISA-based assays with colon-cancer-specific-2 or TIMP 1 (Holten-Andersen et al, 2002; Leman et al, 2008; deVos et al, 2009; Church et al, 2010) proteins, allowing combinations similar to the CEA results in our study, and offering the prospect of a more specific blood test screen for colorectal cancer. In our study, CEA did not add greatly to the AUROC, and the results are included largely to show that this marker, even in combination with others, has little diagnostic value. Nevertheless, the addition of protein and DNA markers may give greater accuracy of such tests and should be considered further.

It may well be that identification of normal patients not requiring other screening interventions will be the ultimate role of cfDNA markers. The Alu 247 fragment as the best single performer in our study, previously showed significant findings discriminating colon cancer, ampullary cancer (Umetani et al, 2006c), and breast cancer patients (Umetani et al, 2006a), and has shown early promise as a universal marker in this role.

Reservations regarding the utility of DNA markers in the normal population have been expressed, with an ovarian study including a population of patients admitted to hospital for treatment with associated benign diseases. Results from this group show raised cfDNA levels at $16 \mathrm{ng} \mathrm{ml}^{-1}$ (Chang et al, 2002), and a reduced diagnostic accuracy. However, these 'benign' conditions included 
patients admitted to hospital with infections, autoimmune disease, postorgan transplant, post-trauma, AIDS, and asthma. All of these conditions are likely to be associated with active inflammation and increased apoptosis. Furthermore, these conditions cause proven increases in circulating DNA (Lui and Dennis, 2002; Lam et al, 2003, 2004; Moreira et al, 2010), and inflammation in a study of circulating DNA histones showed a clear correlation with DNA levels (Holdenrieder et al, 2001). Raised cfDNA has been noted in rheumatoid disease, blamed on antibody-bound cfDNA (Zhong et al, 2007). Such severely ill patients are unlikely to be represented in large numbers within the population attending screening visits and would be rapidly removed from the test pool. We therefore believe that confounding factors can be assessed by clinical history, allowing study of clinically relevant populations that would show clear differences in DNA levels even in precancerous conditions. Other studies suggest that physiological changes with age and even menstruation, driven by apoptosis within the endometrium, are not associated with changes in cfDNA (Polcher et al, 2010).

In conclusion, cfDNA markers offer an interesting prospect for a blood test screen in cancer, with our results showing the possibilities in early colon cancer and precancerous polyps. We have identified a combination marker in our population able to discriminate 'normal' patients with common medical problems from patients with benign polyps and operable cancers, although this requires validation in a larger independent series.

\section{ACKNOWLEDGEMENTS}

This research was funded by the Portsmouth Hospitals NHS Trust 'Rocky' Appeal and by Mr Tony Maxse MBE and friends, to whom we are most grateful. We are grateful to Dr Bernie Higgins for statistical advice.

\section{REFERENCES}

Allen JI (1995) Molecular biology of colon polyps and colon cancer. Semin Surg Oncol 11: 399-405

Board RE, Williams VS, Knight L, Shaw J, Greystoke A, Ranson M, Dive C, Blackhall FH, Hughes A (2008) Isolation and extraction of circulating tumor DNA from patients with small cell lung cancer. Ann NY Acad Sci 1137: $98-107$

Boni L, Cassinotti E, Canziani M, Dionigi G, Rovera F, Dionigi R (2007) Free circulating DNA as possible tumour marker in colorectal cancer. Surg Oncol 16(Suppl 1): S29-S31

Cancer Research UK (2011) Cancer Stats. http://info.cancerresearchuk.org/ cancerstats/

Catarino R, Ferreira MM, Rodrigues H, Coelho A, Nogal A, Sousa A, Medeiros R (2008) Quantification of free circulating tumor DNA as a diagnostic marker for breast cancer. DNA Cell Biol 27: 415-421

Chang HW, Lee SM, Goodman SN, Singer G, Cho SK, Sokoll LJ, Montz FJ, Roden R, Zhang Z, Chan DW, Kurman RJ, Shih Ie M (2002) Assessment of plasma DNA levels, allelic imbalance, and CA 125 as diagnostic tests for cancer. J Natl Cancer Inst 94: 1697-1703

Chiu RW, Poon LL, Lau TK, Leung TN, Wong EM, Lo YM (2001) Effects of blood-processing protocols on fetal and total DNA quantification in maternal plasma. Clin Chem 47: 1607-1613

Church TR, Wandell M, Lofton-Day C, Mongin S, Blumenstein BA, Allen JI, Roesch T, Snover D, Day R, Ransohoff DF (2010) Prospective clinical validation of an assay for methylated SEPT9 DNA in human plasma as a colorectal cancer screening tool in average risk men and women $\geqslant 50$ years. Gastroenterology 139(1): e18

deVos T, Tetzner R, Model F, Weiss G, Schuster M, Distler J, Steiger KV, Grutzmann R, Pilarsky C, Habermann JK, Fleshner PR, Oubre BM, Day R, Sledziewski AZ, Lofton-Day C (2009) Circulating methylated SEPT9 DNA in plasma is a biomarker for colorectal cancer. Clin Chem 55: $1337-1346$

Diehl F, Li M, Dressman D, He Y, Shen D, Szabo S, Diaz Jr LA, Goodman SN, David KA, Juhl H, Kinzler KW, Vogelstein B (2005) Detection and quantification of mutations in the plasma of patients with colorectal tumors. Proc Natl Acad Sci USA 102: 16368-16373

Diehl F, Schmidt K, Choti MA, Romans K, Goodman S, Li M, Thornton K, Agrawal N, Sokoll L, Szabo SA, Kinzler KW, Vogelstein B, Diaz Jr LA (2008) Circulating mutant DNA to assess tumor dynamics. Nat Med 14: $985-990$

Dobrzycka B, Terlikowski SJ, Mazurek A, Kowalczuk O, Niklinska W, Chyczewski L, Kulikowski M (2010) Circulating free DNA, p53 antibody and mutations of KRAS gene in endometrial cancer. Int J Cancer 127: $612-621$

Drew WL (2007) Laboratory diagnosis of cytomegalovirus infection and disease in immunocompromised patients. Curr Opin Infect Dis 20: 408-411

Ellinger J, Albers P, Muller SC, von Ruecker A, Bastian PJ (2009a) Circulating mitochondrial DNA in the serum of patients with testicular germ cell cancer as a novel noninvasive diagnostic biomarker. BJU Int 104: $48-52$

Ellinger J, Bastian PJ, Haan KI, Heukamp LC, Buettner R, Fimmers R, Mueller SC, von Ruecker A (2008) Noncancerous PTGS2 DNA fragments

of apoptotic origin in sera of prostate cancer patients qualify as diagnostic and prognostic indicators. Int J Cancer 122: 138-143

Ellinger J, Muller SC, Stadler TC, Jung A, von Ruecker A, Bastian PJ (2009b) The role of cell-free circulating DNA in the diagnosis and prognosis of prostate cancer. Urol Oncol 29(2): 124-129

Federici A, Giorgi Rossi P, Borgia P, Bartolozzi F, Farchi S, Gausticchi G (2005) The immunochemical faecal occult blood test leads to higher compliance than the guaiac for colorectal cancer screening programmes: a cluster randomized controlled trial. J Med Screen 12: 83-88

Fenocchi E, Martinez L, Tolve J, Montano D, Rondan M, Parra-Blanco A, Eishi Y (2006) Screening for colorectal cancer in Uruguay with an immunochemical faecal occult blood test. Eur J Cancer Prev 15: $384-390$

Flamini E, Mercatali L, Nanni O, Calistri D, Nunziatini R, Zoli W, Rosetti P, Gardini N, Lattuneddu A, Verdecchia GM, Amadori D (2006) Free DNA and carcinoembryonic antigen serum levels: an important combination for diagnosis of colorectal cancer. Clin Cancer Res 12: $6985-6988$

Gauthier VJ, Tyler LN, Mannik M (1996) Blood clearance kinetics and liver uptake of mononucleosomes in mice. J Immunol 156: 1151-1156

Harbeck RJ, Hoffmann AA, Carr RI (1975) Studies on the nature of circulating DNA in systemic lupus erythematosus (SLE). J Rheumatol 2: $194-203$

Holdenrieder S, Stieber P, Bodenmuller H, Busch M, Fertig G, Furst H, Schalhorn A, Schmeller N, Untch M, Seidel D (2001) Nucleosomes in serum of patients with benign and malignant diseases. Int J Cancer 95: $114-120$

Holten-Andersen MN, Christensen IJ, Nielsen HJ, Stephens RW, Jensen V, Nielsen OH, Sorensen S, Overgaard J, Lilja H, Harris A, Murphy G, Brunner N (2002) Total levels of tissue inhibitor of metalloproteinases 1 in plasma yield high diagnostic sensitivity and specificity in patients with colon cancer. Clin Cancer Res 8: 156-164

Hosgood III HD, Liu CS, Rothman N, Weinstein SJ, Bonner MR, Shen M, Lim U, Virtamo J, Cheng WL, Albanes D, Lan Q (2010) Mitochondria DNA copy number and lung cancer risk in a prospective cohort study. Carcinogenesis 31: $847-849$

http://www.cancerscreening.nhs.uk/bowel (2010) Report to the English Bowel Cancer Screening Working Group, September 2004. Online

Huang P, Zhang YX, Zhao T (2009) [The relationship between copy number and microsatellite instability of mitochondrial DNA in colorectal cancer]. Zhonghua Nei Ke Za Zhi 48: 837-840

Jung M, Klotzek S, Lewandowski M, Fleischhacker M, Jung K (2003) Changes in concentration of DNA in serum and plasma during storage of blood samples. Clin Chem 49: 1028-1029

Kirsch C, Weickmann S, Schmidt B, Fleischhacker M (2008) An improved method for the isolation of free-circulating plasma DNA and cell-free DNA from other body fluids. Ann NY Acad Sci 1137: 135-139

Kolesnikova EV, Tamkovich SN, Bryzgunova OE, Shelestyuk PI, Permyakova VI, Vlassov VV, Tuzikov AS, Laktionov PP, Rykova EY (2008) Circulating DNA in the blood of gastric cancer patients. Ann NY Acad Sci 1137: $226-231$ 
Kopreski MS, Benko FA, Kwee C, Leitzel KE, Eskander E, Lipton A, Gocke CD (1997) Detection of mutant K-ras DNA in plasma or serum of patients with colorectal cancer. Br J Cancer 76: 1293-1299

Lam NY, Rainer TH, Chan LY, Joynt GM, Lo YM (2003) Time course of early and late changes in plasma DNA in trauma patients. Clin Chem 49: $1286-1291$

Lam NY, Rainer TH, Chiu RW, Joynt GM, Lo YM (2004) Plasma mitochondrial DNA concentrations after trauma. Clin Chem 50: $213-216$

Lee TH, Montalvo L, Chrebtow V, Busch MP (2001) Quantitation of genomic DNA in plasma and serum samples: higher concentrations of genomic DNA found in serum than in plasma. Transfusion 41: $276-282$

Leman ES, Schoen RE, Magheli A, Sokoll LJ, Chan DW, Getzenberg RH (2008) Evaluation of colon cancer-specific antigen 2 as a potential serum marker for colorectal cancer. Clin Cancer Res 14: 1349-1354

Liggett T, Melnikov A, Yi QL, Replogle C, Brand R, Kaul K, Talamonti M, Abrams RA, Levenson V (2010) Differential methylation of cell-free circulating DNA among patients with pancreatic cancer versus chronic pancreatitis. Cancer 116: $1674-1680$

Lin CS, Wang LS, Tsai CM, Wei YH (2008) Low copy number and low oxidative damage of mitochondrial DNA are associated with tumor progression in lung cancer tissues after neoadjuvant chemotherapy. Interact Cardiovasc Thorac Surg 7: 954-958

Locker GY, Hamilton S, Harris J, Jessup JM, Kemeny N, Macdonald JS, Somerfield MR, Hayes DF, Bast Jr RC (2006) ASCO 2006 update of recommendations for the use of tumor markers in gastrointestinal cancer. J Clin Oncol 24: 5313-5327

Lui YY, Dennis YM (2002) Circulating DNA in plasma and serum: biology, preanalytical issues and diagnostic applications. Clin Chem Lab Med 40: $962-968$

Margraf S, Logters T, Reipen J, Altrichter J, Scholz M, Windolf J (2008) Neutrophil-derived circulating free DNA (cf-DNA/NETs): a potential prognostic marker for posttraumatic development of inflammatory second hit and sepsis. Shock 30: $352-358$

Moreira VG, Prieto B, Rodriguez JS, Alvarez FV (2010) Usefulness of cellfree plasma DNA, procalcitonin and C-reactive protein as markers of infection in febrile patients. Ann Clin Biochem 47: 253-258

Muller I, Beeger C, Alix-Panabieres C, Rebillard X, Pantel K, Schwarzenbach $\mathrm{H}$ (2008) Identification of loss of heterozygosity on circulating free DNA in peripheral blood of prostate cancer patients: potential and technical improvements. Clin Chem 54: 688-696

Ore L, Hagoel L, Lavi I, Rennert G (2001) Screening with faecal occult blood test (FOBT) for colorectal cancer: assessment of two methods that attempt to improve compliance. Eur J Cancer Prev 10: 251-256

Parente F, Marino B, DeVecchi N, Moretti R, Ucci G, Tricomi P, Armellino A, Redaelli L, Bargiggia S, Cristofori E, Masala E, Tortorella F, Gattinoni A, Odinolfi F, Pirola ME (2009) Faecal occult blood test-based screening programme with high compliance for colonoscopy has a strong clinical impact on colorectal cancer. Br J Surg 96: 533-540

Perego RA, Corizzato M, Brambilla P, Ferrero S, Bianchi C, Fasoli E, Signorini S, Torsello B, Invernizzi L, Bombelli S, Angeloni V, Pitto M, Battaglia C, Proserpio V, Magni F, Galasso G, Mocarelli P (2008) Concentration and microsatellite status of plasma DNA for monitoring patients with renal carcinoma. Eur J Cancer 44: 1039-1047

Polcher M, Ellinger J, Willems S, El-Maarri O, Holler T, Amann C, Wolfgarten M, Rudlowski C, Kuhn W, Braun M (2010) Impact of the menstrual cycle on circulating cell-free DNA. Anticancer Res 30: $2235-2240$

Rago C, Huso DL, Diehl F, Karim B, Liu G, Papadopoulos N, Samuels Y, Velculescu VE, Vogelstein B, Kinzler KW, Diaz Jr LA (2007) Serial assessment of human tumor burdens in mice by the analysis of circulating DNA. Cancer Res 67: 9364-9370

Richards MA (2009) The size of the prize for earlier diagnosis of cancer in England. Br J Cancer 101(Suppl 2): S125-S129

Stroun M, Lyautey J, Lederrey C, Olson-Sand A, Anker P (2001) About the possible origin and mechanism of circulating DNA apoptosis and active DNA release. Clin Chim Acta 313: 139-142

Sunami E, Shinozaki M, Higano CS, Wollman R, Dorff TB, Tucker SJ, Martinez SR, Mizuno R, Singer FR, Hoon DS (2009) Multimarker circulating DNA assay for assessing blood of prostate cancer patients. Clin Chem 55: 559-567
Sunami E, Vu AT, Nguyen SL, Giuliano AE, Hoon DS (2008) Quantification of LINE1 in circulating DNA as a molecular biomarker of breast cancer. Ann NY Acad Sci 1137: 171-174

Taback B, O’Day SJ, Hoon DS (2004) Quantification of circulating DNA in the plasma and serum of cancer patients. Ann NY Acad Sci 1022: $17-24$

Taback B, Saha S, Hoon DS (2006) Comparative analysis of mesenteric and peripheral blood circulating tumor DNA in colorectal cancer patients. Ann NY Acad Sci 1075: 197-203

Thierry AR, Mouliere F, Gongora C, Ollier J, Robert B, Ychou M, Del Rio M, Molina F (2010) Origin and quantification of circulating DNA in mice with human colorectal cancer xenografts. Nucleic Acids Res 38(18): $6159-6175$

Tomita H, Ichikawa D, Sai S, Morimura R, Murayama Y, Komatsu S, Ikoma D, Tani N, Ikoma H, Fujiwara H, Kikuchi S, Okamoto K, Ochiai T, Kokuba Y, Sakakura C, Sonoyama T, Hagiwara A, Otsuji E (2007) Quantification of circulating plasma DNA fragments as tumor markers in patients with esophageal and gastric cancer. Gan To Kagaku Ryoho 34: $1908-1910$

Toth K, Galamb O, Spisak S, Wichmann B, Sipos F, Leiszter K, Molnar J, Molnar B, Tulassay Z (2009) [Free circulating DNA based colorectal cancer screening from peripheral blood: the possibility of the methylated septin 9 gene marker]. Orv Hetil 150: $969-977$

Tuaeva NO, Abramova ZI, Sofronov VV (2008) The origin of elevated levels of circulating DNA in blood plasma of premature neonates. Ann NY Acad Sci 1137: $27-30$

Umetani N, Giuliano AE, Hiramatsu SH, Amersi F, Nakagawa T, Martino S, Hoon DS (2006a) Prediction of breast tumor progression by integrity of free circulating DNA in serum. J Clin Oncol 24: 4270-4276

Umetani N, Hiramatsu S, Hoon DS (2006b) Higher amount of free circulating DNA in serum than in plasma is not mainly caused by contaminated extraneous DNA during separation. Ann NY Acad Sci 1075: $299-307$

Umetani N, Kim J, Hiramatsu S, Reber HA, Hines OJ, Bilchik AJ, Hoon DS (2006c) Increased integrity of free circulating DNA in sera of patients with colorectal or periampullary cancer: direct quantitative PCR for ALU repeats. Clin Chem 52: $1062-1069$

van Dam L, Hol L, de Bekker-Grob EW, Steyerberg EW, Kuipers EJ, Habbema JD, Essink-Bot ML, van Leerdam ME (2010) What determines individuals' preferences for colorectal cancer screening programmes? A discrete choice experiment. Eur J Cancer 46: 150 - 159

van der Drift MA, Hol BE, Klaassen CH, Prinsen CF, van Aarssen YA, Donders R, van der Stappen JW, Dekhuijzen PN, van der Heijden HF, Thunnissen FB (2010) Circulating DNA is a non-invasive prognostic factor for survival in non-small cell lung cancer. Lung Cancer 68: $283-287$

van der Vaart M, Pretorius PJ (2010) Is the role of circulating DNA as a biomarker of cancer being prematurely overrated? Clin Biochem 43: 26-36

Vernon SW (1997) Participation in colorectal cancer screening: a review. J Natl Cancer Inst 89: 1406-1422

Vogelstein B, Kinzler KW (2004) Cancer genes and the pathways they control. Nat Med 10: 789-799

Wang BG, Huang HY, Chen YC, Bristow RE, Kassauei K, Cheng CC, Roden R, Sokoll LJ, Chan DW, Shih Ie M (2003) Increased plasma DNA integrity in cancer patients. Cancer Res 63: $3966-3968$

Wang M, Block TM, Steel L, Brenner DE, Su YH (2004) Preferential isolation of fragmented DNA enhances the detection of circulating mutated k-ras DNA. Clin Chem 50: 211-213

Xia P, An HX, Dang CX, Radpour R, Kohler C, Fokas E, Engenhart-Cabillic R, Holzgreve W, Zhong XY (2009) Decreased mitochondrial DNA content in blood samples of patients with stage I breast cancer. $B M C$ Cancer 9: 454

Xue X, Teare MD, Holen I, Zhu YM, Woll PJ (2009) Optimizing the yield and utility of circulating cell-free DNA from plasma and serum. Clin Chim Acta 404: 100-104

Yoon KA, Park S, Lee SH, Kim JH, Lee JS (2009) Comparison of circulating plasma DNA levels between lung cancer patients and healthy controls. J Mol Diagn 11: $182-185$

Zhong XY, von Muhlenen I, Li Y, Kang A, Gupta AK, Tyndall A, Holzgreve W, Hahn S, Hasler P (2007) Increased concentrations of antibody-bound circulatory cell-free DNA in rheumatoid arthritis. Clin Chem 53: $1609-1614$ 